\title{
数値シミュレーションに基づく 短時間豪雨に対する遠賀川流域の洪水と 飯塚市街地の浸水特性の検討 NUMERICAL INVESTIGATION OF CHARACTERISTICS OF FLOOD FLOW IN THE ONGA RIVER BASIN AND INUNDATION FLOW IN IIZUKA CITY DUE TO TORRENTIAL RAIN
}

\author{
秋山壽一郎 ${ }^{1} \cdot$ 重枝未玲 $^{2} \cdot$ 野村心平 $^{3}$ \\ Juichiro AKIYAMA, Mirei SHIGE-EDA and Shinpei NOMURA \\ 1フェロー会員 Ph.D. 九州工業大学大学院教授 工学研究院建設社会工学研究系 \\ ( (804-8550 北九州市戸畑区仙水町1-1) \\ 2正会員 博士(工) 九州工業大学大学院准教授 工学研究院建設社会工学研究系 (同上) \\ 3学生会員 九州工業大学大学院 工学府建設社会工学専攻博士前期課程（同上）
}

\begin{abstract}
Numerical simulations of flood flow in the Onga river basin and inundation flow in the Iizuka-city area due to torrential rain were performed by a numerical model for rainfall-runoff in watershed and flood inundation process in urban area with flood disaster-reduction system such as sewer network and drainage pump station. The rain-fall runoff, flood flow in rivers and inundation flows on the ground and freesurface-pressurized flow in the sewer network were simulated by a distributed hydrological model, the 2D free-surface flow model and dynamic network model for free-surface-pressurized flow combined with the Preissmann slot respectively. The characteristics of flood flow and inundation flow in Iizuka-city in the Onga river basin due to several torrential rain were examined based on the numerical results.
\end{abstract}

Key Words : torrential rain, rainfall-runoff, flood flow, inundation flow, numerical simulation, Onga river basin, Iizuka city

\section{1. はじめに}

近年，想定を超えた豪雨により，甚大な被害が生じて いる. 近年の水害は, 短時間の局地的な大雨によって引 き起こされることが特徵であり，2012年7月の九州北部 豪雨災害では，熊本県阿蘇市の阿蘇乙姫において，観測 史上最大の3時間雨量288.5mmを記録している.

このような短時間豪雨の雨量は, 河川計画における降 雨継続時間内の降雨量としては少なく, その年超過確率 も小さい. 従って, 河川計画を検討する際の降雨として 選定される可能性は小さい. しかし，現実に被害が生じ ており，このような豪雨に対する備えは必要である。そ のためには，短時間豪雨に対する流域，河道，氾濫原で の雨水のレスポンスを知ることは不可欠である. 今後, 年最大日雨量が増大寸ることが予測(1),2されていることか ら，その重要性はま寸ます高くなると考えられる. 短時間豪雨に対寸る流域, 河道, 氾濫原での雨水のレ
スポンスを検討寸るためには，降雨外力からの流出，洪 水，氾濫の一連のプロセスを予測し，その結果に基づき 被害評価を行うことが必要となる。「統合型降雨流出・ 洪水汇濫モデル」33,4),5,69 はそのためのツールの一つであ り，同モデルを用いた浸水予測に基づき，経済被害評価 を行えるようになってきているの,7)。著者らも，降雨外力 から流出，洪水，汇濫の一連のプロセスを予測できる 「流域流出・都市域汇濫解析モデル」 ${ }^{8)}$ に経済被害評価 を組み込むことで，「都市域浸水・減災対策検討シミュ レータ」9)を開発し，同モデルが流域の雨水の挙動，河 道での洪水流の挙動, 都市域での詳細な氾濫流の挙動だ けでなく, 経済被害も予測可能である9 ことを示した. このようなモデルを用いて，短時間豪雨に対する流域， 河道, 汇濫原での雨水のレスポンスを検討し，どのよう な雨に対して，どの河道区間や氾濫原で危険な状況にな るのか, 被害状況はどの程度になるかを把握することは, 危機管理対策を講じる上で有用であると考えられる。

本研究は, 以上のような背景を踏まえ, 遠賀川流域と 


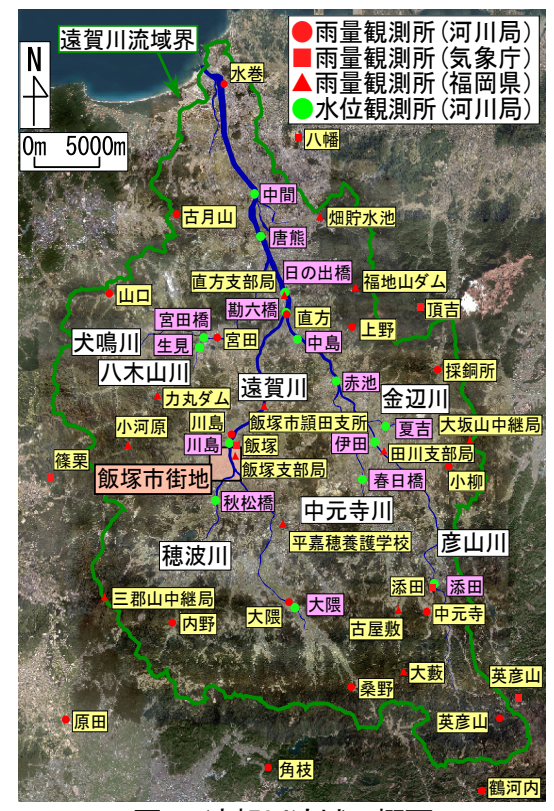

図-1 遠賀川流域の概要

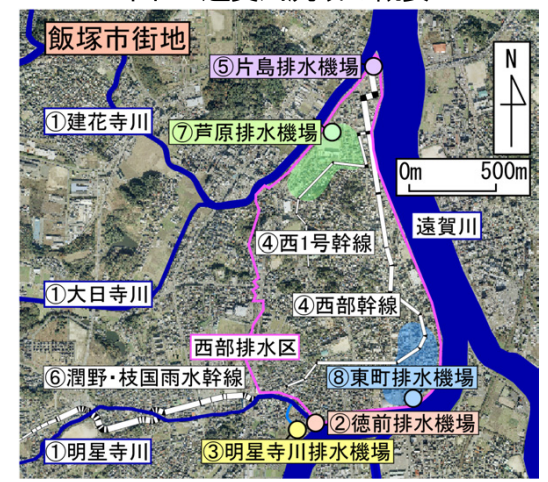

図-2 飯塚市街地の西部排水区の治水システム

飯塚市街地を対象に，複数の降雨波形および空間分布 の短時間豪雨に対して，「都市域浸水・減災対策検討シ ミュレータ」による遠賀川流域の洪水，氾濫状況，被害状 況の予測を行い，その結果に基づき，短時間豪雨に対す る遠賀川流域の洪水特性および飯塚市街地での浸水特性 について検討したものである.

\section{2. 遠賀川流域と飯塚市街地の概要}

\section{（1）遠賀川と流域の概要}

遠賀川流域は，流域内の人口密度が 650 人 $/ \mathrm{km}^{2}$ と比較 的高く, 三方を福智山地, 英彦山地, 三郡山地といった 山々に囲まれている。流域面積は $1,026 \mathrm{~km}^{2}$ であり，土地 利用は，森林が約 $52 \%$, 水田や果樹園等の農地が約 $19 \%$, 宅地等市街地が約 $18 \%$ ，荒地が約 $6 \%$ を占めている.

遠賀川は，幹川流路延長 $61 \mathrm{~km}$ の一級河川であり，そ の支川には穂波川・中元寺川・彦山川・金辺川・八木山 川・犬鳴川・笹尾川・黒川・西川などがある．遠賀川の 計画基準点は日の出橋であり，そこでの計画高水位は T.P. $10.46 \mathrm{~m}$, 計画高水流量は $4,800 \mathrm{~m}^{3} / \mathrm{s}$, 整備計画目標流 量は3, $800 \mathrm{~m}^{3} / \mathrm{s}$ である. 図-1に遠賀川流域の航空写真と雨 量・水位観測所を示す.
遠賀川では度々洪水が発生し，特に明治22年7月，明 治38年7月，昭和10年6月，昭和16年6月，昭和26年6月に 大洪水が発生している，最近では平成15年7月に，集中 豪雨による内水氾濫が生じ甚大な被害が生じている．特 に，遠賀川の中下流域では低地部に住宅地が発達してお り，頻繁に内水汇濫が生じている.

\section{（2）飯塚市街地の概要}

飯塚市街地は中下流域に位置しており，支川の汇濫に よる内水汇濫被害が度々生じている. 平成15年の九州豪 雨災害時には飯塚市の旧飯塚地区では最大で約 $1.5 \mathrm{~m} の$ 浸 水深となり，歴史ある劇場や中心商店街，文化施設をは じめとして周辺一体が大きな被害を受け，床上浸水 1,569棟, 床下浸水724棟をはじめ電気・水道・ガスなど のライフラインにも大きな被害が生じている. 図-2は, 飯塚市街地西部排水区の治水システムを示したものであ る. 現在，西部排水区の治水システムは，(1) 明星寺川, 建花寺川, 大日寺川の中小河川(図-2中の(1)), (2) 明星 寺川下流の徳前排水機場(排水能力 $16.0 \mathrm{~m}^{3} / \mathrm{s}$ )(図中の(2),

(3) 明星寺川の分流河川下流の明星寺川排水機場(排水能 力 $26.0 \mathrm{~m}^{3} / \mathrm{s}$ ) (図中の(3), (4) 西部幹線(幅1400 3600 mm× 高さ1120～2160mm×長さ $2633 \mathrm{~m}$ ), 西1号幹線(直径 $250 \sim$ $1650 \mathrm{~mm} \times$ 長さ $1494 \mathrm{~m}$ )の二つの幹線を有する下水道網(図 中の (4), (5) 西部幹線末端の片島排水機場(排水能力 $12.66 \mathrm{~m}^{3} / \mathrm{s}$ ) (図中の (5)), (6)潤野 - 枝国雨水幹線(幅 $1200 \mathrm{~mm} \times$ 高さ $1200 \sim 4500 \times 2000 \mathrm{~mm} \times$ 長さ $2460 \mathrm{~m}$ ) (困中の (6), (7)芦原排水機場(排水能力 $3.0 \mathrm{~m}^{3} / \mathrm{s}$ ) と東町排水機場 (排水能力 $2.2 \mathrm{~m}^{3} / \mathrm{s}$ )(図中の (7), 8)(ハッチの地域の雨水排 水を担当) で構成されている.

\section{3. 都市域浸水・減災対策検討シミュレータの概 要}

「都市域浸水・減災対策検討シミュレータ ${ }^{99}$ は，(1)任意 の降雨外力から, 流域での雨水の挙動を把握した上で, 精度の高い本川の洪水追跡を介して，都市域での詳細な 浸水プロセスの予測を行う「流域流出・都市域氾濫解析 モデル」と(2)浸水による被害額を評価する「経済被害評 価モデル」とで構成される. 以下にその概要を示寸．モ デルの詳細は参考文献を参照されたい9).

\section{（1）流域流出・都市域汇濫解析モデルの概要}

流域流出・都市域氾濫解析モデル9 ${ }^{9}$ は，(1)セル分布型 流出解析モデル ${ }^{10)}$, (2)平面2次元洪水追跡モデル ${ }^{10)}$, (3)都 市域氾濫解析モデル9)の3つのモデルで構成される. モデ ル(1)で小流域と都市域に含まれる斜面部の雨水の挙動解 析と河川への流出計算を行う. 河川への流出, 斜面部か らの汇濫原への雨水の流出を考慮して本川下流端の水位 を境界条件として，モデル(2)と(3)で本川の洪水追跡，支 川の洪水流, 汇濫原の汇濫流および下水道流を一体的に 

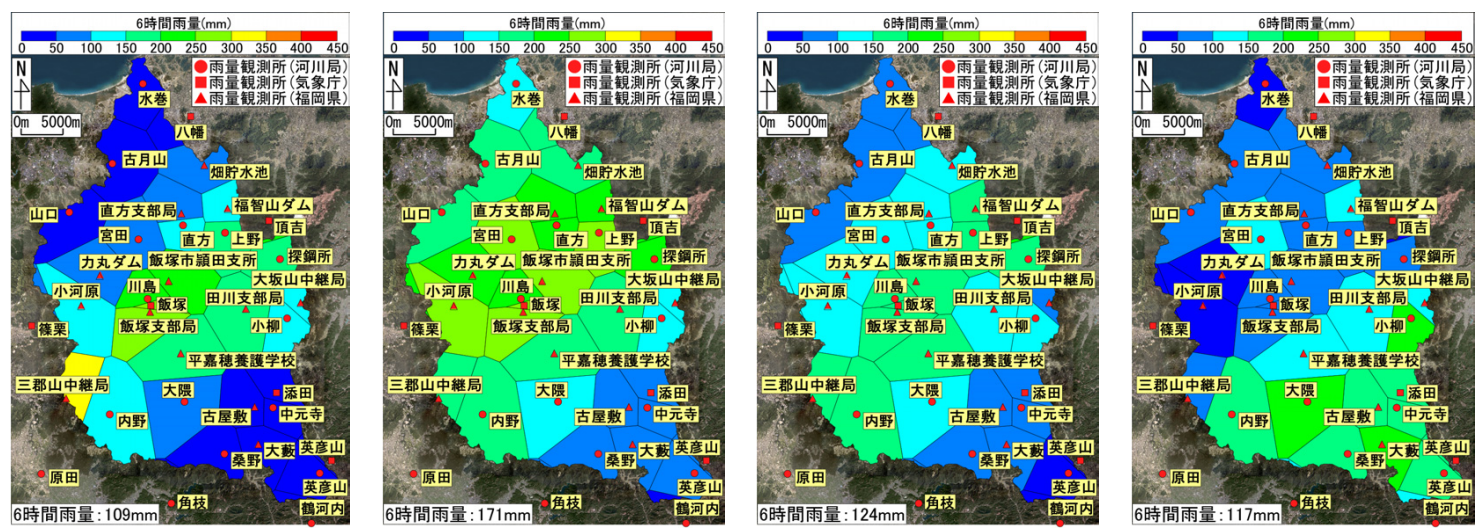

図-3 代表的な出水の6時間雨量の分布図
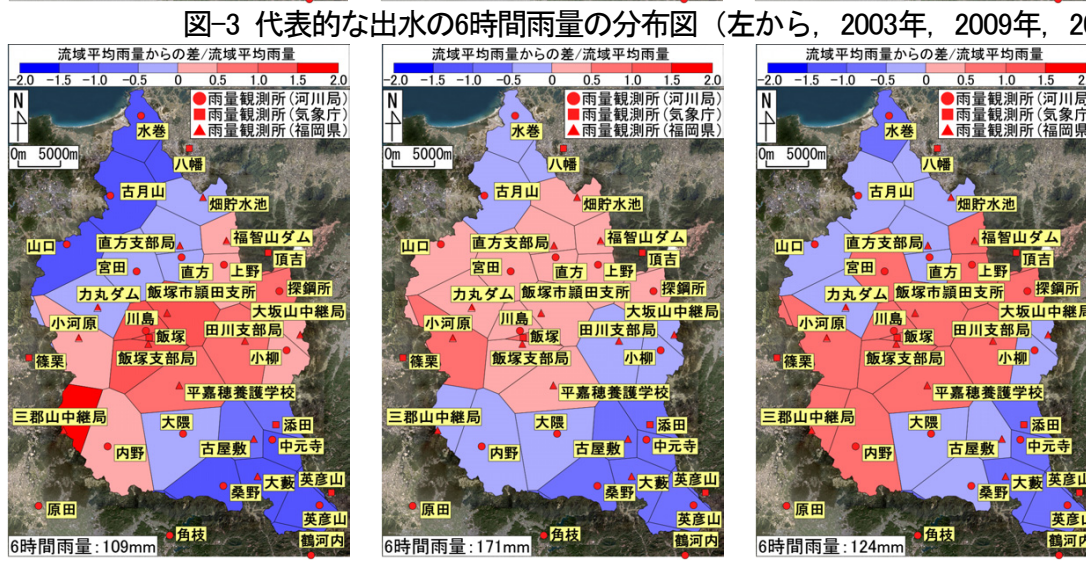

2010年, 2012年)

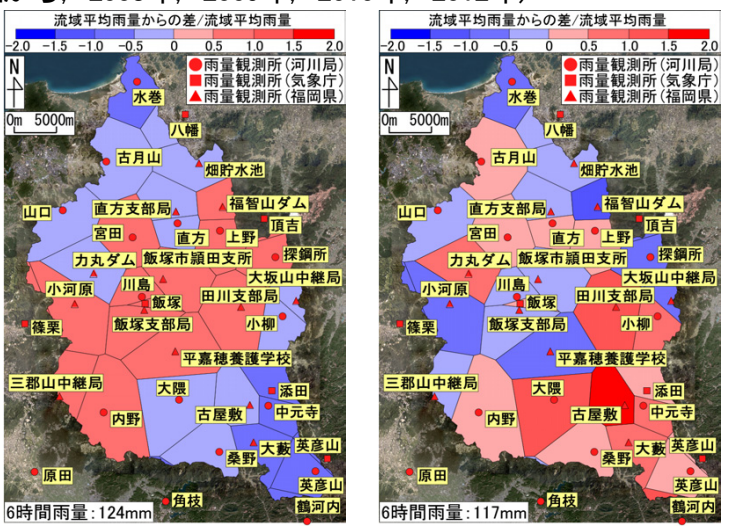

図-4 各観測所の6時間雨量と流域平均雨量との差の分布図（左から，2003年，2009年，2010年，2012年）

解析寸る. モデル(1) (3)の詳細については参考文献 ${ }^{11)} に$ 示す通りである.

\section{（2）経済被害評価モデル}

経済被害評価モデルでは直接被害のみを評価するモデ ルである. (1)街区中の家屋のポリゴンデータ，(2)田畑の ポリゴンデータ, (3)産業分類別従業者数, (4)住宅の建て 方別世帯数, 世帯の経済構成別一般世帯数, (5)世帯の家 族類別一般世帯数のデータから (1) 一般資産被害, (2) 農産物被害, (3) 公共土木施設等被害を推定するモデル である，その評価方法は，家屋位置での浸水深の評価方 法9)除いては, 治水経済調査マニュアル $\left.{ }^{12}\right)$ と同様であ る. なお, 本研究では, 解析結果から得られる最大浸水 深に基づき, 浸水深が $0.01 \mathrm{~m}$ よりきく, $0.45 \mathrm{~m}$ よりさ い場合を床下浸水として被害額を算定した.

\section{4. 解析条件の概要}

\section{（1）降雨外力の設定}

2012年7月の九州北部豪雨災害では，先述した熊本県 阿蘇市の阿蘇乙姫をはじめ, 多くの雨量観測所で，観測 史上最大を記録している．遠賀川流域に隣接する山国川 流域では，9箇所の観測所で3時間雨量の観測史上最大を 更新しており，流域平均の3時間雨量で147mm，6時間雨 量で194mmを記録している，遠賀川流域でも，雨域が少 しでもずれていれば，同様な雨が観測された可能性があ
る. 従って, ここでは, 降雨継続時間を6時間とし, 山 国川の6時間流域平均雨量194mmを基準として降雨外力 を設定した．図-3に，降雨外力の検討に用いた代表的な 出水である2003年，2009年，2010年，2012年の7月の実 績降雨に基づく6時間雨量の分布図を示す. 図中には各 降雨の流域平均6時間雨量も併せて示している.

図-4は，図-3の6時間雨量と流域平均雨量との差を分 布図にしたものである. コンターの赤色は流域平均より も降雨量が大きな観測所，青色は小さな観測所を表して いる．これより，(1) 2003年，2009年，2010年は中流域 に集中した降雨であること，2003年と2009年では2003年 の方が上流域まで降雨が集中していること，また，2003 年と2010年の分布が似ていること，(2)一方，2012年は 他の降雨とは異なり，上流域に集中した降雨であること， などがわかる．これらを踏まえ，ここでは2003年，2009 年, 2012年の実績降雨に基づき，6時間雨量が194mm と なるように各観測所の降雨ハイエトグラフを作成し，降 雨外力とした. 作成したハイエトグラフは, 流域平均降 雨ハイエトグラフと各観測所の降雨ハイエトグラフであ る. その作成方法は次の通りである. まず, (1)図-5に示 寸流域平均の降雨ハイエトグラフを作成する. 次に, (2) 各観測所と時間に対して, 図-4のような時間雨量と流域 平均雨量との差の分布図を作成する. (3) (1)の流域平均 降雨ハイエトグラフの6時間雨量が194mmとなるように, 降雨倍率方式で一律に引き伸ばすことで, 図-5に示す流 域平均降雨ハイエトグラフを作成する. (4) (3)で作成し た流域平均降雨ハイエトグラフに，(2)で作成した差分を 
表-1 解析条件

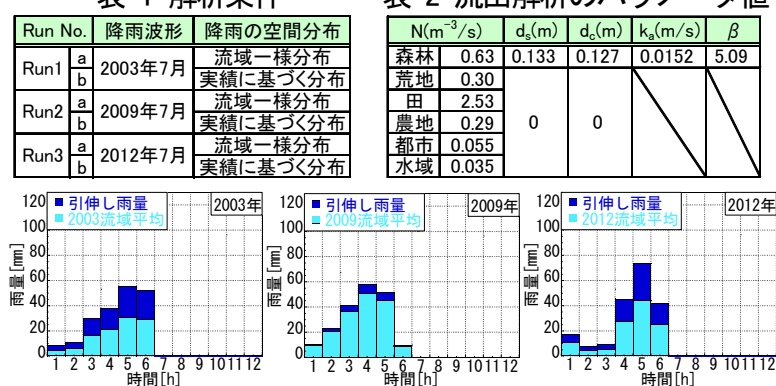

図-5 引き伸ばした流域平均降雨ハイエトグラフ

加えることで，各観測所の降雨ハイエトグラフを作成す る. 各観測所で(4)の方法を採用したのは, 降雨倍率方式 による非現実的な降雨量を避けることができ，降雨制限 方式に比べより空間分布の違いが明確になると考えたた めである．なお，全ての降雨に対して時間降雨量の最大 值は125mmであった．図-5に，引き伸ばした流域降雨八 イエトグラフを示す。 なお，降雨量194mmを遠賀川の降 雨継続時間である48時間の雨量とすると, 確率規模は 1/3程度になる.

\section{（3）解析条件}

解析は，2003年7月の実績降雨に基づくRun1，2009年 7月の実績降雨に基づくRun2，2012年7月の実績降雨に 基づくRun3を行い，それぞれのRunで流域平均降雨八イ エトグラフを流域一様に与えたRun1-a, Run2-a, Run3-a, 各観測所の実績降雨に基づき空間分布を与えたRun1-b,

Run2-b，Run3-bを行った. 表-1に解析の条件を示す.

解析対象領域は，飯塚市街地と遠賀川本川とその支川 の穂波川, 彦山川, 金辺川, 中元寺川, 犬鳴川, 八木山 川の計7つの河川である。いずれのRunについても初期 条件には，流域平均時間雨量 $5 \mathrm{~mm}$ を定常的に与えた解析 結果を与えた.

分布型流出解析ではモデルパラメータとして，参考文 献の方法 ${ }^{13)}$ で求めた表-2に示寸值を用いた. ここに， $N=$ 等価粗度係数, $k_{\mathrm{a}}=$ 重力水が卓越するA層内の透水係数, $d_{\mathrm{c}}=$ マトリックス部の最大保水量を水深で表した值, $d_{\mathrm{s}}=$ 重力水を含めて表層土中に保水しうる最大水深， $\beta$-重力 水部と不飽和水部との飽和透水係数の比である.

洪水追跡では，河道横断面に2009年の断面を，粗度係 数には河道計画で用いられた平均值 0.035 おえた。 な お，越水が生じた場合には，限界水深を境界条件として 与え, 完全越流状態で河道から流出すると仮定した. ま た，水位が計画高水位を超えた場合でも破堤は考慮して いない.

都市域氾濫解析では，明星寺川下流端の徳前排水機 場・明星寺川排水機場については操作ルールに従い，芦 原排水機場と東町排水機場については排水を担当する地 域の単位面積当り排水能力に基づき排水させた．また， 西部排水区の雨水下水道網下流端の片島排水機場につい ては, 下水道網末端に排水流量を与えた。
計算格子には三角形非構造格子を用い, 計算領域内の 河川や街路などの線形に対して分割数を設定した後, メッシュジェネレータを用いて解析対象領域を三角形の 計算メッシュに分割した。総メッシュ数は37,440個で あった.

\section{5. 結果と考察}

\section{（1）計画基準点の日の出橋での洪水特性}

図-6は，遠賀川の計画基準点である日の出橋の水位・ 流量ハイドログラフと水位と流量との関係について解析 結果を示したものである. なお，図中には計画高水位， 計画高水流量, 整備計画目標流量, 解析結果より作成し た水位流量曲線も併せて示している. 水位八イドログラ フから，(1) いずれのRunにおいても計画高水位まで水 位が上昇すること，(2) Run1-a，Run2-a，Run3-aでは時 間のずれはあるものの，ピーク值，水位上昇速度のいず れも同程度であること, (3) Run1-b, Run2-b, Run3-bで は，ピーク水位がRun1-b，Run3-b，Run2-bの順で大きい こと，(4) 雨量が流域で一様なRun1-a 3-a と空間分布を 持つRun1-b 3-bを比較すると, Run1 と3では空間分布が あるRun1-bと3-bの方が，増水時の水位上昇速度が速く なること，Run2ではあまり変化しないこと，などがわ かる. 流量ハイドログラフから, (1) ピーク流量はRun1b，Run3-bで整備計画目標流量の $3,800 \mathrm{~m}^{3} / \mathrm{s}$ を超えること， その他のケースは小さいこと, (2) Run1-a, Run2-a, Run3-aでは，水位八イドログラフと同様，時間のずれは あるものの，ピーク值，水位上昇速度ともに同程度であ ること, (3) Run1-b, Run2-b, Run3-bではピーク流量は, 水位と同様にRun1-b, Run3-b, Run2-bの順で大きいこと, また，Run1-b，Run3-bは同程度であるが，Run2-bは小さ くなること，(4) 雨量が流域で一様なRun1-a 3-a と空間 分布を持つRun1-b 3-bを比較すると, 空間分布がある Run1-b とRun3-bでは増水時の流量の増加率は大きく, Run2-bでは小さくなること，などがわかる．水位と流量 との関係から, (1) Run1-a, Run2-a, Run3-aでは, 水位 と流量との関係に大きな変化はなく, 同じ形でループを 描くこと，(2) Run1-b, Run2-b, Run3-bでは，いずれも ループを描くが，Run1-b，Run3-bとRun2-bではその形は 異なること，(3) 減水時のループは，いずれもRunにつ いても同様な形になること，(4) 水位流量曲線から整備 計画目標流量 $3,800\left(\mathrm{~m}^{3} / \mathrm{s}\right)$ から求まる水位は $10.72 \mathrm{~m}$ であり, 計画高水位程度となること，などがわかる。

以上をまとめると, 遠賀川の計画基淮点である日の出 橋水位観測所での短時間豪雨に対するレスポンスは次の 通りである. (1)水位は, 降雨波形・空間分布に関係なく 計画高水位を超える. (2)一方, 流量は, 空間分布によっ ては整備計画目標流量を超える. (3)水位・流量のいずれ もRun1-bのようにRun2-bの中流域よりも上流側に集中寸 




（a）水位ハイドログラフ

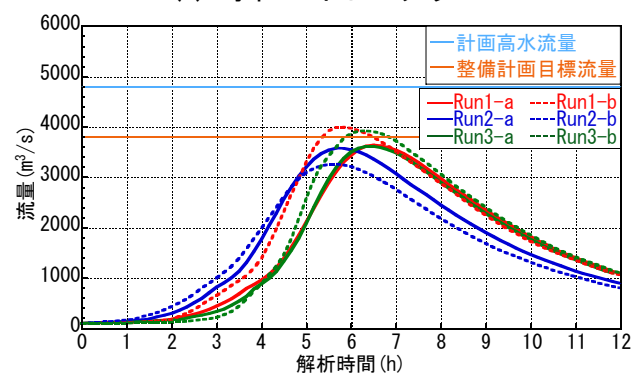

(b) 流量ハイドログラフ

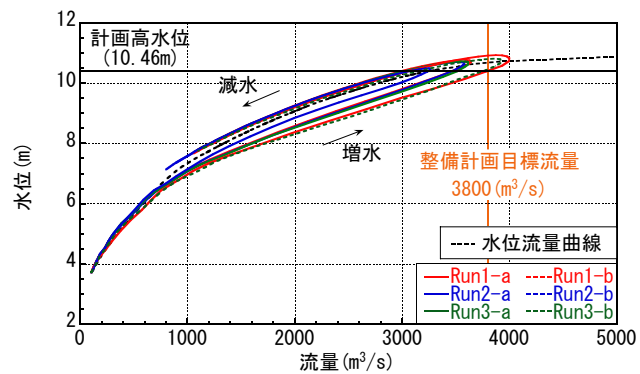

（c）水位と流量との関係

図-6 計画基準点の日の出橋での水位 · 流量ハイドログラフと 水位と流量との関係

る空間分布や，Run3-bのように上流域に降雨が集中寸る 空間分布の場合に大きくなる傾向にある.

2012年7月の九州北部豪雨災害では48時間降雨量が

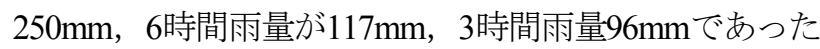
が，日の出橋では既往最大水位 $10.17 \mathrm{~m}$ 記録しているこ とを踏まえると，上記の検討結果は妥当であると考えら れる．以上のことは，短時間豪雨に対寸る遠賀川の危機 管理対策の必要性を示唆している.

\section{（2）各河川の最大水位と越水状況}

図-7は，遠賀川とその支川の穗波川，彦山川のピーク 水位の縦断変化を示したものである.これらより，(1) Run1 3-a 比較から降雨波形による違いはないこと，(2) Run1 3-bの比較から，空間分布による違いは，遠賀川の 上 中流と彦山川の全区間で生じること，(3) Run3-bのよ うな空間分布の場合，彦山川および遠賀川上流で水位が 上昇し危険な状況になること，(4) Run1-bのような降雨 の場合, 遠賀川中流で水位が上昇し危険な状況になるこ と，などがわかる．図-8は，水位が堤防を越える区間を まとめたものである。これらの区間では，当然のことな がら, 外水汇濫に対する備えが必要になる. なお，日の 出橋より下流では越水は生じなかった。

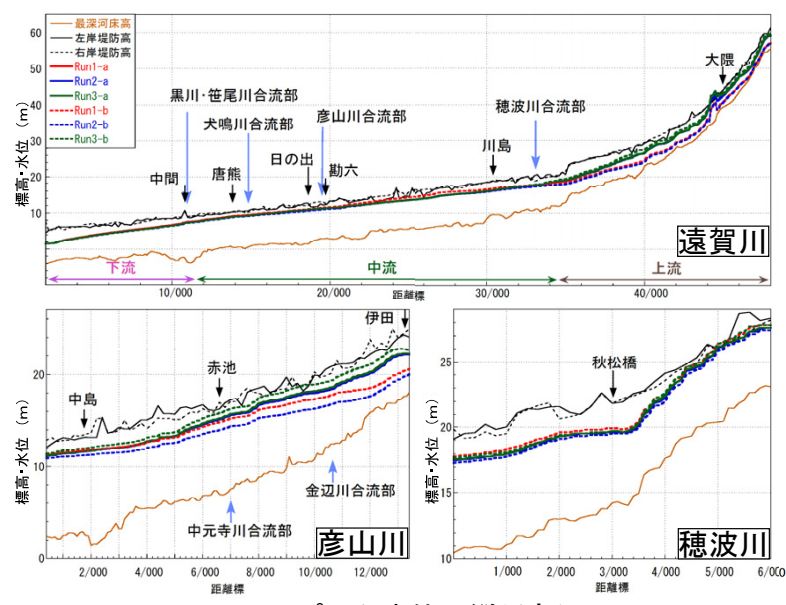

図-7 ピーク水位の縦断変化

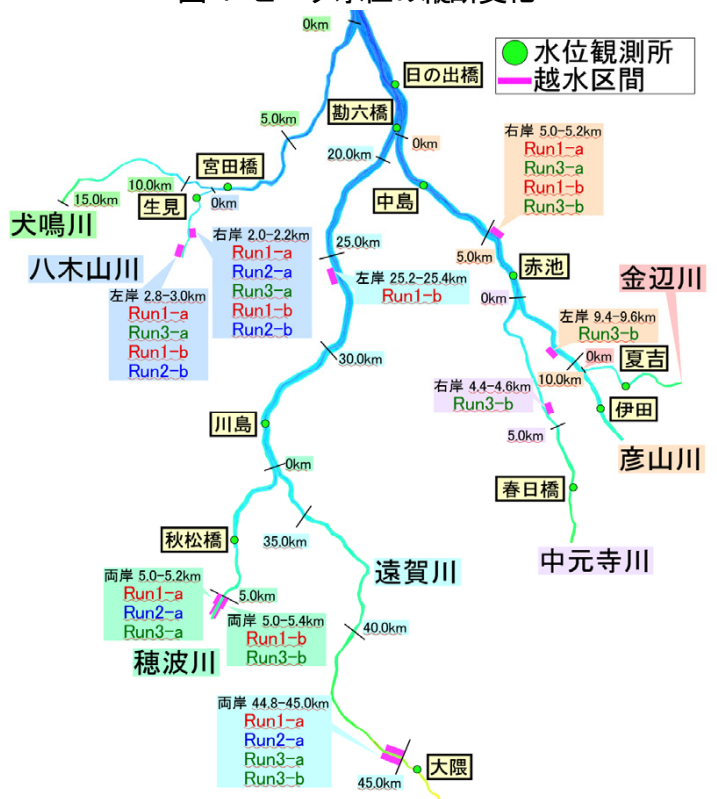

図-8 各河川の越水発生区間

\section{（3）飯塚市街地の浸水被害}

図-9は, 飯塚市街地の西部排水区について，最大浸水 深を示したものである.これらより，(1) Run1-a Run3-a では, 最大時間雨量 $73 \mathrm{~mm}$ となるRun3-aで最大浸水深が 高くなること，(2) Run1-b Run3-bでは，飯塚支部局雨量 観測所で比較的強い雨が降るRun1-b(図-4)で明星寺川周 辺の浸水深が，小河原，力丸ダム雨量観測所で比較的強 い雨が降るRun2-b(図-4)で建花寺川周辺の浸水深が高く なること， Run3-bが最も浸水深が小さくなること，(3) Run1 3-a とRun1 3-bを比較すると, 降雨が中流域に集中 するRun1-bとRun2-bで浸水深が大きくなるが，上流域に 集中寸るRun3-bが最も小さくなること，などがわかる.

表-3に各Runの一般資産被害額を示寸. 当然のことなが ら浸水深が大きくなるRun2-bで被害額は最も大きく, 72 億円程度の被害が予想される.

以上をまとめると，飯塚市街地での短時間豪雨に対寸 るレスポンスは次の通りである. (1)降雨波形・空間分布 によって浸水状況は大きく影響を受ける. (2)降雨が空間 で一様な場合, 時間降雨量の大きな場合に浸水深は最大 となる. (3)降雨に空間分布がある場合には, 降雨が中流 


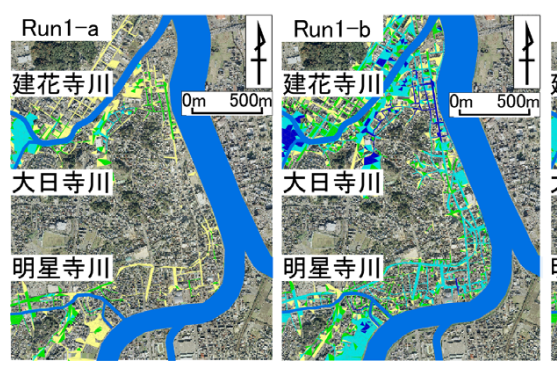

表-3 一般資産被害額

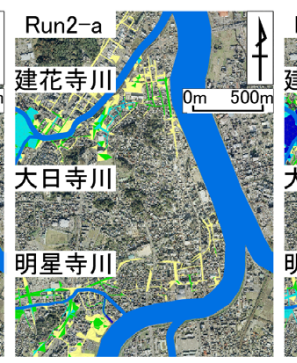

図-9 各Runの最大浸水深

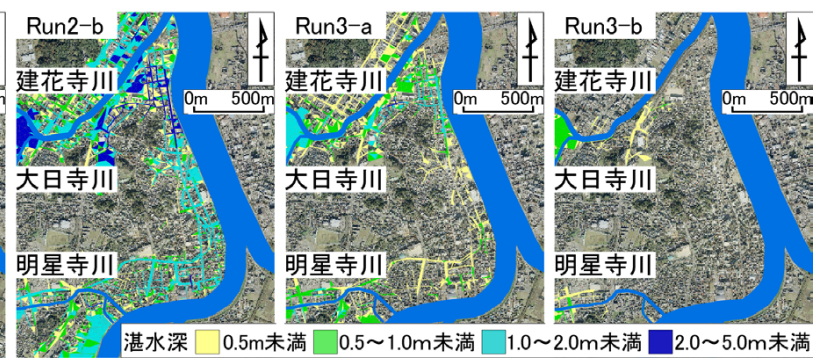

\begin{tabular}{r|c|c|c|c|c|c|} 
Run No. & $1-\mathrm{a}$ & $1-\mathrm{b}$ & $2-\mathrm{a}$ & $2-\mathrm{b}$ & $3-\mathrm{a}$ & $3-\mathrm{b}$ \\
\hline 一般資産被害額(億円) & 9.6 & 67.3 & 8.7 & 72 & 17.3 & 0.4 \\
\hline
\end{tabular}

域に集中した場合に，浸水する可能性が高くなる，飯塚 市街地の周辺の雨量観測所で，(4)明星寺川の流域の約8 割が含まれる飯塚支部局雨量観測所に降雨が集中寸る場 合には，明星寺川からの氾濫と下水道の排水不良のため の浸水により明星寺川周辺の浸水深が最大に，(5)小河原， 力丸ダム雨量観測所に降雨が集中寸る場合には，建花寺 川からの汇濫と下水道排水不良により建花寺川周辺の浸 水深が最大となる.

以上から，飯塚市街地は中流域に降雨が集中した際に 水害が生じる可能性が高く，特に，飯塚支部局，小河原， 力丸ダム雨量観測所の雨量は, 飯塚市街地の浸水状況に 大きな影響を及ぼすため，同雨量観測所は，避難指示等 を判断する上での一つの指標になると考えられる.

\section{6. おわりに}

本研究は，遠賀川流域と飯塚市街地を対象に，複数の 降雨波形および空間分布の集中豪雨に対して，「都市域 浸水・減災対策検討シミュレータ」による遠賀川流域の洪 水・汇濫状況・被害状況の予測を行い，その結果に基づ き，豪雨に対する遠賀川流域の洪水特性および飯塚市街 地での浸水特性について検討した．その結果，(1) 遠賀 川流域に短時間豪雨が降った場合には，計画基準点の日 の出橋で計画高水位以上になる可能性が高く, 被害を軽 減するための備えが必要であること，(2) 各河川で越水 が発生する可能性の高い区間は図-8であること，(3) 飯 塚市街地は中流域に豪雨が集中した場合に浸水被害が大 きくなる傾向にあり，飯塚支部局，小河原，力丸ダム雨 量観測所の雨量は, 飯塚市街地の浸水の判断基準になる こと，などの危機管理上有用な知見を得ることができた。

謝辞 : 本研究を実施するに当たり, 遠賀川河川事務所の 関係各位にはデータの提供など多大な協力を得た。また， 本研究を遂行寸るに当り, 本学学部4年生の丹生捺貴さ 几，石川知弘君，鷹尾忍君にはデー夕整理等で協力を得 た. ここに記して感謝の意を表します.

\section{参考文献}

1）国土交通省：地球温暖化に伴う気候変動について，大規模
水害対策に関する専門調査会, 2007.

2) 小林健一郎, 寶 馨, 中北英一：全球気候モデル出力を用 いた日本域の 100 年確率日降水量の将来予測, 水工学論文 集, 第54巻, pp.223-228, 2010.

3) 辻本哲郎, 本守眞人, 安部友則, 山田哲夫 : 氾濫シミュ レーション手法の開発と東海豪雨災害の再現，河川技術論 文集, 第8巻, pp.121-126, 2002.

4) 戸田圭一, 井上和也, 村瀬賢, 市川 温, 横尾英男 : 豪雨 による都市域の洪水氾濫解析, 土木学会論文集, No. 633/II-53, pp.1-10, 2000.

5) 川池健司, 井上和也, 戸田圭一, 野口正人 : 低平地河川 流域での豪雨による都市汇濫解析，土木学会論文集，No. 761/II-67, pp.57-68, 2004.

6) 小林健一郎, 寶 馨, 奥勇一郎 : 統合型降雨流出 - 洪水氾 濫モデルによる佐用町洪水災害分析と経済被害推定, 水工 学論文集，第55巻，p.S_949-S_954， 2011.

7) 小林健一郎，寶 馨，佐野 肇，津守博通，関井勝善 : 損 害保険に応用可能な国土基盤情報準拠型の分布型降雨流 出・洪水氾濫モデルの開発，土木学会論文集BI(水工学), Vol.68, No.4, pp.I_1069-I_1074, 2012.

8）秋山壽一郎，重枝末玲，小園裕司，草野浩之: 治水システ ムを考慮した飯塚市街地の都市域汇濫解析と被害軽減効果 の検討，水工学論文集，第55巻，pp.S_943-S_948， 2011.

9) 秋山壽一郎, 重枝未玲, 草野浩之: 都市域浸水・減災対 策検討シミュレータによる飯塚市街地の浸水被害評価，土 木学会論文集B1(水工学)，Vol.68，No.4，pp.I_1063-I_1068, 2012.

10）重枝末玲，秋山壽一郎，草野浩之，野村心平：高解像度 風上解法を用いた遠賀川流域の分布型流出・平面 2 次元洪 水追跡と改修効果の評価, 土木学会論文集B1(水工学),

Vol.68, No.4, pp.I_1429-I_1434, 2012.

11) 秋山壽一郎, 重枝末玲, 小園裕司: 流域特性を考慮した都 市域汇濫解析モデルと都市域での浸水プロセスの予知，水 工学論文集, 第54巻, pp.919-924, 2010.

12）国土交通省 : 治水経济調查マニュアル（平成17年度版）

13）重枝未玲，秋山壽一郎，野村心平：実測水位に基づく分布 型流出・平面2次元洪水追跡モデルのパラメータ最適化法, 河川技術論文集，第18巻，pp.459-464， 2012. 